\title{
The Russian-American Relations during the Period (2000-2008) - Prospects of Competition and Cooperation
}

\author{
fawzi A.Tayyem ${ }^{1} \&$ Saddah A.Al habashneh ${ }^{1}$ \\ ${ }^{1}$ Department of Political Science, University of Mutah, Karak, Jordan \\ Correspondence: fawzi A.Tayyem, Department of Political Science, University of Mutah, Karak, Jordan. \\ E-mail: f_tayyem1948@yahoo.com
}

Received: March 5, 2012 Accepted: March 15, 2012 Online Published: May 21, 2012

doi:10.5539/jpl.v5n2p116 URL: http://dx.doi.org/10.5539/jpl.v5n2p116

\begin{abstract}
This study targets researching in the Russian-American relations during the period (2000-2008) by using the descriptive and statistical methodologies, as the study shows the following:

First: The Russian foreign politics during the reign of president Putin witnessed a mass turning especially towards the United States of America.

Second: President Putin suggested some main principles for the Russian foreign politic, known as "Putin's Principles" as he tried to mix between the Euro-Atlantic and the New Eurasian.

Third: There are many aspects of conflict between Russia and the United States especially in expanding the sovereignty of NATO over the countries of Eastern Europe, and USA's try to control South East Asia countries annexed to Russian, supporting the colorful revolutions especially in Georgia and Ukraine.

Fourth: Notwithstanding the aspects of conflict between Russia and the United States, this didn't prevent the existence of aspects of cooperation between both countries, especially in the fields of Economy, Energy, and the fight against terrorism.
\end{abstract}

Keyords: Russian-American relations, Vladimir Putin, multipolar system, national security

\section{Introduction}

When Vladimir Putin ascended the throne of Russia in January 2000, he was keen on deepening the Eurasian trend in Russia's foreign politics. In June 2000, he suggested some principles, known as "Putin's principles" but the most important principle was developing Russia's role in the multipolar world that don't accept the sovereignty of one regime.

But, the events of 9/11 in the United States, and what followed them in the worldwide strategies of the United States towards the attacking war, and considering "terrorism" as the most important case that faces the American policy, all of these have led to the existence of turning in the Russian foreign politics towards the Euro-Atlantic trend, as Putin was keen on exploiting the American turning by making a correspondent turning towards supporting the new American strategy through introducing Russia as a partner in the fight against terrorism, hoping to gain an American support against the Chechen separatist movement, disposal of the adverse Afghan system (Taliban system) and getting and American economic support.

But soon, Russia has transferred from this trend to the alternative system during the reign of Putin as well.

The fact is that Putin tried to mix between the Euro-Atlantic and the Eurasian trends in one new political mixture that achieves the Russian's ruling place, and the variety of alternatives on one hand, and not to get in clash with USA and Europe on the other.

\section{Objectives}

This study aims to analyze the political behavior of both countries concerning the ability of cooperation, difference, competition, and the way which each country of both has used in order to achieve its national interest in the cadre of a network of international relations used by the United States to siege Russia in the time when Russia tries to break this siege and founding a network of coalitions and associations by which it will be able to limit the American role in the world. 


\section{Importance}

The importance of this study springs not only from being analyzing the nature of relations between USA and Russia in a certain period, but as from being able to be a reference to what will be the shape of the coming presidential period between USA and Russia. In the period which this study targets to research in, two presidents ascended the throne, each one of them had his certain and exact vision about the national interest of his country, as Putin tried to retain Russia's place among countries of the world which owed to the Soviet Union in the past, but in USA, it was led by a charismatic character which has its own vision about the national interest of the country, this vision springs from ideological-religious reference, and this leadership was not sufficient of what Clinton, the former president has left, but it sought to govern the whole world in the cadre of serious classification of the good and evil camps.

\section{Problem}

The problem of the research springs from the problematic Russian-American relations, and analyzing the factors that affect it positively or negatively from the beginning of the reign of president Putin in 2000 till its end in 2008 in a try to acknowledge and predict what these relations will bear in the aftermaths.

\section{Methodology}

This research will be based upon two methodologies; first: the descriptive methodology which will focus on description of the development of the Russian-American relations in the period (2000-20008) and the rationalities of this period. Second; the analytical methodologies which will focus on analyzing the perspectives of this relation and the trends which relate to it through relating them to the different factors and differences which affected it during the period of researching.

\section{Questions}

This study will try to answer these questions:

What are the aspects of competition and cooperation in the Russian-American relations in the period (2000-2008) concerning the issues and matters which established the pillars of this study?

\section{Divisions}

Based upon the objectives of the study, its problems and questions, it will be divided into the following divisions:

First: The concept of the national security of a country.

Second: The aspects of competition between USA and Russia.

Third: The aspects of cooperation between USA and Russia.

\section{First: The concept of the national security of a country}

The foreign politics of a country targets keeping its security and national interest by various means, political, economic and even military.

The process of the country's protection of its dignity and national security is divided into three stages:

\section{A: The Interior Stage}

It relates to protecting the society from the exterior risks, especially the risks that are supported by exterior powers.

\section{B: The Regional Stage}

It relates to the relations between the country and the surrounding countries in the same geographic region, the matter which is called "The Regional International System".

\section{$\mathrm{C}$ : The International Stage}

It relates to the relations between the country and the international society, this stage is affected by the country's relations with other ones.

Some major countries are not sufficient of achieving this target as keeping their national security, and then their behavior in their foreign politics, but it seeks to request power, as the latter is considered as a main means to achieve the biggest goals in the international politics, what is meant here by "power" is extending the military, economic, and political sovereignty as the request of power will be the direst target of countries.

The traditional way of achieving these goals is represented in imposing the countries' will over others, the matter 
which is called the military, economic of political colonialism.

The contemporary way to achieve this goal is imposing the powers over other countries without intervention in their interior politics.

This policy is based upon extending powers, and gaining more sovereignty over the affairs of the international society and intervention in any national matters that are important even if they didn't touch their interests, the matter which will make them use the system of coalitions, the variety of power resources in order to keep its status as a major country and what is related to this system of such merits.

Historically, the resources of achieving the national security has been varied a lot between countries, as these countries have known the clash and pressing on other countries, and they also have known the common cooperation between them when they have acknowledged that this clash will affect their security.

Based upon this, the study will be keen on researching on the nature of relations between Russia and USA during the reign of Vladimir Putin (2000-20008) in matters of the relations of competition and cooperation caused by difference or correspondence in interests of both countries, as USA is now considered the biggest power in the world after the collapse of the Soviet Union. United States of America always is keen on controlling the international relations and the current international system through facing and challenging Russia.

\section{Second: The Aspects of Competition between Russia and USA}

Because of the international played by USA and Russia, the pillars of competitions have been varied; the same took place with issues on which they were competing whether in the geographic field, or the matters of these issues, taking into account that Russia's behavior is just reactions to the deeds of America.

In the forthcoming paragraph, we will tackle these important issues:

\section{(1) United States of America, Mid and East Europe Countries}

United States of America has been sufficient in the Cold War in its position towards the countries of mid and east Europe, which is the hide park of Russia by the political and media incitement besides defaming the iron fest policy of the Russian Regime against the reform movements in order to throw them away from the cadre of the Russian sovereignty without receiving any political or military support from the United States, the matter which enables these countries from achieving this target, but after signing the Treaty of Helsinki between Russia and USA in 1975, in which the Soviet Union has committed to keep the human rights, respect them, stopping suppression against freedoms, and civil uprising with an iron fest, supported by the USA, as done also by the anti-powers with Moscow in Warsaw Coalition.

In addition to what is mentioned before, the United States sought to extend the NATO towards the east in spite of the Russian opposition, this keen interest was in favor of the United States and the countries of Eastern Europe, as this country was a field of a historical clash between Germany and Russia, thus USA wanted to add the countries of eastern Europe to the NATO, otherwise else this will shape a great risk against the USA, which has a target from this which is sieging Germany and Russia, especially when the relations between countries became very powerful during the reign of Putin in Russia and Schroeder in Germany, to the extent that this relation may considered as a German-Russian coalition against USA.

Additionally, the strategy of Bush the son towards the countries of mid and eastern Europe was based upon supporting the colorful revolutions in this region, as this revolutions were based upon civil resistance, oppositions, and demonstrations in addition to the use of a unified symbol as a rose, so USA was keen on supporting these revolutions in order to use these countries as militaries bases to siege Russia, or giving them military aids and the chance to be members in the NATO.

For instance, USA was able to extend its powers to Georgia, as it supported Georgia with modern military equipment in order to help it with its fight against terrorism, as member of Al-Qaeda used an English tunnel to use it as a safe place. Also, Georgia is considered as an important base for USA especially in its intervention in Iraq in order to prepare the airports to serve the American forces. Washington is afraid from the success of the Iraqi forces in attacking the American forces in Turkey, while the Georgian bases will be safe.

The importance of Georgia springs from the continuance of the traditional American method in preventing the choice of Russia to sovereign the region of Caucasus by turning Georgia as an American ally in a region rich of oil resources.

Additionally, America has supported the independence of Kosovo Province which was belonging to Yugoslavia before chattering and considered Serbia as a part of it; this is considered as a try from the USA to fill the emptiness in the Balkans after the collapse of the Socialist group in one hand, and enabling the USA from 
controlling the oils of Eastern Asia on the other hand, and distribution of this oil in a gas pipe like the line of (Ambo) which starts from the port of Boughs in Bulgaria to the Black Sea and spans for (900 km) in Macedonia to the port of (floor) in Albania, this line gives the machines to use it safely and quickly in addition to its low prices from Mid-Asia to USA, so USA built a military base in Kosovo to secure this line.

\section{(2) The USA and Asian countries}

\section{a. The USA and the Medium Asia}

The medium-Asian and Caucasian region has become an arena for competition between the USA and Russia, that is because this region has a strategic location as it is the key of the Arabic Gulf region - dominating it means controlling all the East in addition to the fuel and gas sources. The USA has extending its powers over this region under "prohibiting the Islamic fundamentalism" as it would aim at protecting its independence from this fundamentalism; in the same time, Russia thinks that this region is its normal power region so it - Russia - has faced the American dominance over this region while the USA - in its tries to minimize the Russian role in this region - seeks to make the medium-Asian and Caucasian countries involve in economical and political problems, which helps the USA to expand the NATO membership by offering the American assistance in all fields: political, economical or military. The rocket shield can be deemed as one of these methods indicating this intervention.

For the purpose of extending the American domination over the region, excluding the Russian effect and preventing the establishment of any strategic regional coalition leaded by Russia in the region, the USA performs these following security procedures:

Supporting the military concentration of its troops and the NATO troops in the military bases in Afghanistan making pressure and intimidation factor against the medium-Asian countries, and as launch stations, getting through in order to strategically control the region and strengthen the cooperation with Azerbaijan and Georgia in the Caucasian region.

Trying to make some medium-Asian countries rent their lands to the USA to build its military bases for the USA and the NATO, that was successful in Uzbekistan and Kyrgyzstan.

Supporting bloodless coups required for many pro-Russian regimes.

\section{b. The USA and the east-south Asian countries}

To better achieve a complete blockade over Russia, the USA intents to enforce its presence in the Asian region Pacific ocean; the American president, Bush the son, make his largest tour in this region in 17 October 2003 as he visited six countries in the East-Asian region (Thailand, Singapore, Indonesia, Australia, Japan, Philippine).

\section{(1) Second course:}

It'd be through holding a number of military alliances with all the countries in the region separately. Those countries are represented in the American-Japanese, American-South Korean, American-Philippines, American-Thailand and American-News eland Australian alliance.

\section{(2) Multi-parties alliance with the countries in the region}

The most prominent features and activities of the regional forum of Asian Association.

\section{(3) Strategic partnership course}

One of the most prominent common military trainings among USA and the countries in the region is the attempt of USA to cooperate with both of Japan and India aiming at embracing China as it's considered a strategic opponent and reject the American sovereignty over the region. In this regard, USA uses a number of cards such as the human rights in China, north Korea and pressure card for the oil Chinese interests abroad card.

As for Japan, it believe that its alliance is insensible matter due to the conflict raised with China whether related to Taiwan or Japan which gave its petroleum companies the right of drilling for the prospected petrol and gas which called the demarcation line in the east China sea.As for India, the USA see it as a reliable alley for confronting the growing Chinese power from one side and the new dangers in the center and south of Asia such as escalation of the Islamic Political Movements opposed to USA from another side. For such reason, USA moved to the strategic understanding with India after incidents of 11 September, 2001 in respect of Kashmir issue

As for the desire of India to promote its relationships and cooperation with USA, it's represented in the India vision of China as a traditional source of threat and its security. In addition to that, it didn't settle their border problems with the other neighbors. 
As for USA, it sees India not just as in parallel to China but also as performing a major role with USA under a complicated network of Asian powers and commercial relations. Moreover.

By such way, USA causes the existence of a strategic axis in Japan and India under the sponsorship of America in face of China.

\section{(4) Russian Position from USA Policies}

When Putin come to be Russian President, he put some principles for Russian foreign policy which was called "Putin Doctrine". He tried to mix between New Euro-Atlantic trend and Euro-Russian Trend. That gives Russia good international place and several alternatives without making any conflict with USA or Europe. Putin did not want Russia to be affiliate country as it was in Yeltsin's period, or in conflict as it was in USSR's period. Therefore, Putin focused on making Russia recovering its role in Asia and Middle East gradually and to cooperate with countries on Pacific Asian Coast.

Russian Military Creed Paper of 2001 issued by Putin in 21 April 2000 considered that the threatening of Russian National Security represented in the following:

a. NATO extension to include more countries from old WARSO which was close to Russian boarders with its Military Facilities.

b. Deploying foreign forces in countries near to Russia boarders, including USA Military bases, in Eastern Europe countries.

Due to West and USA extension in Russian back areas, Putin policies was not limited on preventive or negative defense against this extension. His policy depended on attacking strategic policy for recovering its influence in these republics. His policy focused on the following pivots:

To depend on civil wars atmosphere which gives Russia the chance to interfere and control post USSR Republics.

To depend on Ethnics Groups against countries that cooperate with West against Moscow.

To Side with one country (post USSR Republics) against the other during boarders disputes.

To maintain Russian Influence inside new Republics, specially Republics that have big Russian Ethnic group in these countries and to support local leaders adherent to Russia.

Putin handling with USA Policy aiming at seeing Russia could be detailed as following:

\section{(1) Russia and Central Asia Countries}

As Russian territory in Asia extends from its utmost east to its utmost west, Russia considered Central Asia Area (which were part of post USSR with huge natural wealth, specially oil and Gas) as its influence area. Russia considered USA influence increase in this area a threat to its interests. In additions, Russia want to prevent strong Islamic blocs on its southern boarders and to control separation disputes in this area. It aims at preventing all forms of regional unite or establishing big country on its boarders. Central Asia countries participated, from the begging, in the Commonwealth of Independent States Assembly. That makes them as allies with Russia. In additions, Russia developed Tashkent Agreement of 1992 which established in the Collective Security Agreement of 2002 and Collective Security Treaty.

The agreement included Russia, Bella Russia, Armenia, Kazakhstan, Tajikistan, Uzbekistan, Moldavia and Kyrgyzstan to be as political military ally and to practice security role in the region extended from Cocas through Central Asia to Eastern Europe countries. It was as an international bloc comparing to NATO which signed, in October 2007 by presidents of member countries who are in the same times members in the treaty during their summit in Tajikistan Capital " Dushanbe", on Protocol

\section{(2) Russian and Eastern Europe}

Eastern Europe area has vital interest for Russian National Security. From this area, any aggressiveness could be directed against Russia. Also, Balkan and Central Europe was the area with start of big wars. In additions, fights among Ethnic, Religious, National Groups could be aroused which could effect negatively on Russia Security. For these reasons, Russia attempted to control this area to be its first defense line against Western Europe and also to prevent any fights in Central Europe. Russia expressed that USSR regime maintained its control on Eastern Europe Area, even if it was forced to use its army (which called Brezhnev Doctrine .

But this policy changed from $90^{\text {th }}$ of previous century. Russian policy did not approach to maintain communist governments in this area, but it accepted to eliminate communists from governing Eastern Europe countries. 
Also, Communists parties amended its regulations to become socialist parties permitting East and West Germany Reunite in 1990.

In Putin's period, Russian Policy took another curve with Eastern Europe. Russia accepted for these countries to be a part of Western Regime, under Euro American Umbrella .Subsequently, Russia focused on bilateral relation with each country separately after it dealt with them in the past according to one policy.

Russia also approached to develop here cooperative relations in the filed of energy. Eastern Europe countries depend mainly on Russia for supporting their needs from Oil and Gas. The project of "South Current" is considered as one of the most important energy projects that has special priority for Russian. This gas pipeline will be extended from Caspian Sea area through Turkey to Austria. The new trends in Putin's period means that Russia has a desire to achieve some kind of partnership and cooperation with Eastern neighbor countries instead of extending hegemony on the area.

But Russia does not allow USA to siege its vital field in Eastern European countries, or penetrating its national security. This construes its position from Georgia. Georgia-Russia conflict is aroused following Georgian troops attempt to overcome Southern Austria by military forces, attacking Russian peace forces found in Austria .

\section{(3) Russia and China Agreement for Facing USA Attempt for Seizing it}

Russia, in Putin period tried to recover lost USSR place. Whereas Russia and China are two giants from Eastern Asia, they agreed to prevent USA from penetrating Eastern and Central Asia. In this case, Russia shall find allies. Therefore, the idea of regional allies come to existence. In 2001, Russia and China signed friendship treaty based on good neighboring and mutual coordination for closing their point of views concerning different regional and international common interests. 11 September 2011 incidence came to support strongly Strategic closeness between Russia and China (due to USA attempts to centralize in Central Asia for a claim of fighting Islamic terrorism). Moscow and Beijing considered this position as American penetrating inside Asia Continent for control Oil and Gas there and seizing Russia and China. This position made Russia and China try to overcome this challenge and attempt to seize or terminating it as possible.

One of the cooperation mechanism between Russia and China in the period between 18-25 August 2005, was military maneuver which was the first military maneuver between the two countries. This maneuver called Peace Mission 2005. It was an attempt from Russia to use China for facing USA. These maneuvers was a message to USA that Russia is still regional and international power to terminate USA Strategic Expectations along seas. That made USA to think thoroughly before going on their reestablishing positions in Asia Continent for serving its future projects and diminishing Russian control in areas subjected to its circle in Central Asia and Cocas in which Busch Administration supported Democratic Revolutions.

\section{(4) Coup d'état attempt and nomination of Washington-allied systems}

For purpose of establishing a strong base in implementation of its strategy aimed at prevailing the military existence in this critical and natural fortune-enriched region.

While the institutional formula of the Russian - Chinese alliance was represented in establishing Shanghais Cooperation Organization (SCO) which forms $60 \%$ of Eurasia lands and $25 \%$ of the world population. The organization has been established in 1996, it was called Shanghais Fifth. At the beginning it included both of Russia and China plus three countries of Central Asia.However the possibility of interest-conflict to happen in the future between both Russian and China due to rapid growth of China in all fields, the common interests between them are greater than the conflict points. The reason behind their similarity is may be their rejection to the American policy and the trials to restore their international position and role which retreated in the recent years for the benefit of Washington progress. Also, the military American prevalence in Afghanistan and a number of Central Asia countries forms a direct threat to the regional and strategic Russian-Chinese interests. The more important event is the document of confirming confidence among the countries group and reducing the number of military forces and their provisions along the borders between the organization countries. In addition, there are a set of treaties in fields of economic-military cooperation.

In an attempt to evaluate capabilities of this organization, it possesses qualifications which make it, in the near future, an international power with strong impact all over the world. It represent a geographical and human extension with no separates, plus the military power of Russia and China, economical capabilities and natural wealth.

For purpose of boaster a serious security cooperation, an a convention has been signed between the organization and Collective Security Treaty Organization (CSTO) on Oct. 2007 which indicates that each one of the two organizations is considered to be an integral part of the organization established by Russian in Eurasia . 


\section{Thirdly: Cooperation aspects between Russian and USA:}

It's prima facie in politics and human relationships in general that there no permanent friendships or permanent hostility but there is always permanent interests. Accordingly, the national interest is the one which should govern the countries policy in respect of competition or cooperation. Through a vision inspired by cooperation not by competition and confrontation with USA, as the case was under the Soviet union, and not by subordination, as the case was in the Yeltsin period, Russian leadership developed a deep belief that there are no longer east or west but just a group of the greatest countries where USA comes in first and that Russia has a strong bond of real interests with USA which are difficult to waive even in the most critical issues affects the Russian interests.

In other words, there is a limit for the conflict arises between the two sides. We find that Russia is keen not to ascend the situation to the diplomatic confrontation and the verbal expressions in objection to the American policy. So it avoid any direct military confrontation arise between them.

Due to the nature of interest between Russian and USA, there are horizons of cooperation in a number of issues which could be highlighted as follows:

\section{(1) Economy and Energy}

For these purposes, Russia has its cooperative relationships and real interests with the USA and European countries. Although the security and political issues are so important, the economical cooperation between the USA and the western Europe is more critical as the Russian leadership is supported by a strategic partnership with the USA and Europe, which represents a common governing trend in the Russian external politics. For the energy sector, Russia is deemed a giant in this field as it has the seventh of the largest fuel reserves in the world and it is the largest country as to the gas reserves. Russia has become the largest producer of the fuel in the world in 2006, and the first country in the world as to the gas exportation. Their exports of the fuel, gas and metals are about $80 \%$ of the total Russian exports. Russia follows a strategy to support its competitive capability in the market of fuel and well controlling the reds for transporting and distributing fuel through its common project with the USA and Europe. The Russian Lukoil is a cooperative cooperation with the American ConocoPhillips, called "Naria Ghar for fuel \& gas" to invest the field of fuel and gas in the northern European region in Russia, as to $70 \%$ of the shares held by the Russian company and $30 \%$ held by the American company.

It does not mean that the cooperation relationships with the USA and Europe, in the field of energy, are smoothly managed, although there is some fear about the increasing Russian fuel powers in the American and European markets. Since the energy sources: fuel \& gas, are not only commercial articles but also strategic and geopolitical ones, this fuel power makes the USA feel afraid about the fuel supplies which can be used by Russia as a political weapon; these fears are emphasized by the crisis when the Russian gas supplies to Ukraine were stopped in 2006, to Belarus in 2007.

In addition to these fears, they are supported by the competition which approaches to be a conflict between Russian, and the USA \& Europe as they are trying to control the fuel wealth of the northern pole amounting $25 \%$ of the international reserves as to fuel and gas.

\section{Terrorism}

The $11^{\text {th }}$ of September, 2001, and its consequences in the USA and its has affected on the USA's international strategy towards the attacking war, considering the terrorism as the focal point of the American external politics; this trend has made the Russian external politics turn to the Euro-Atlantic orientation as Putin has intended to invest the American orientation by making another similar one to support the American strategy.

Russia's goals which it aims from participating in the international antiterrorist campaign, can be outlined in dealing with the USA as a partner which contributes in making the international resolutions, recognizing its powers in the Medium Asia and introducing the war in Chechnya in the range of the antiterrorist war. Despite the Russian support since the first moments of the war declaration against Talban, Russia didn't directly intervene with the coalition countries; thus, this support is ordinary as Washington's success in dropping the Talban regime is supporting Russia's interests as it considers that the fundamentalist power in the Medium Asia constitutes a danger against its national security, as Moscow was accusing Talban of providing the Chechnya's fighters with the military and moral supports. Therefore, Russia, due to its situation, had expected that it would gain political benefits i.e. more support from Washington and the western countries to face the Chechnya's fighters and more economical support to enable Russia accelerate the procedures to join the World Trade Organization WTO.

Although America has intended to expand the NATO membership to include countries which were a part of the 
Soviet Union (Estonia - Latvia - Lithuania), the coordination with NATO has become one of the priorities of the Russian external politics as Russia thinks that the coalition shall be determine an international role for Russia as a nuclear power and passing the obstacles against the development of the Russian army to enable it deal with the new crisis as the Chechnya crisis.

Russia has soon changed its approach for many reasons, the most important one is the individualist politics of the USA after the $11^{\text {th }}$ September 2011, thus smashing the Russian role when the USA ignored the Russian opposition against the Iraq conquer and the consultation with Russia about Kosovo region.

\section{Conclusion}

Though the previous discussion of the Russian-American relations during the period 2000-2008, and the answer for the study question: (what is the prospects of the competition and the cooperation in the Russian-American relations during the period 2000-2008 in relation to the issues and events constituting the axis of those relations?), it illustrates as follows:

The Russian president, since he took over the presidency, has intended to deepen the Euro-Russian orientation in the Russian external politics; thus, in June 2000 he introduced many principles for the Russian external politics called "Putin principle"; in the introduction of those principles, there are the development of Russia's role in a multi-pole world which is not governed by only one major force, and the restoration of the Russia's role in Asia and the Middle East, and not to allow for the West to marginalize the Russian role in the international relations.

But the $11^{\text {th }}$ September 2011, caused some change in the Russian external politics towards the Euro-Atlantic orientation through supporting the American strategy in its antiterrorist war. Although Russia has changed this trend soon, due to some factors, the most important ones are the Russia's objection against expanding the NATO to include the eastern European countries, the America's try to control the South East Asia which is controlled by Russia, supporting the colored revolutions particularly Georgia and Ukraine as Russia has tried to mix between the Euro-Atlantic trend and the new Euro-Russian one in a new political alloy to achieve an advance international prestige for Russia.

On the other hand, however there are many conflicting and competitive aspects between Russia and America, there are still cooperative aspects between both of them, specially in economy, energy and anti-terrorism.

\section{References}

Bakr Bashir, Poland between satisfaction and frustration European American, Al-Khaleej, UAE; November2, 2007.

Bashir, Abdulfattah, dimensional strategic maneuvers Russian-Chinese Journal of International Politics, Number 162, October 2005, folder 40, p 128.

Borisova, Jana, Russia's cooperation with Europe in the field of energy, novosti, 24/3/2007.

Civil, Abdullah, Chinese competition - the Japanese newspaper civilized dialogue, Number1365.2November2005.

Dawisha, Karer, Gorbachev and Eastern Europe, world policy journal, 3(2), spring 1986, pp 279-280.

Diab, Ahmed, Russia and the major powers in Asia, Journal of International Politics, Number 167, folder 42.2007, p 42.

Diab, Ahmed,op. cit. p. 109.

Helmy, Nadia, the regional competition from the perspective of China, Journal of International Politics, Number 183, January 2011, folder 46, p.72

Heyadi, Zahra, U.S. events in the Caucasus, Iranian anthology, Center for Political and Strategic Studies, Al AHRAM, the number 17.2001, p 42.

Hmbash, Ali. (1988). Political Science, Misurata, Libyan house for publication and distribution, advertising, p 344.

Imam, Mohamed Refaat, the U.S. presence in Georgia, to penetrate the Caucasus, Journal of International Politics, Number 148, April 2002, folder 37, p 133.

International Encyclopedia Of Social Science, 2, The Macmillan company and Free Press, USA, 1968, p.p.39-40.

Kamel, Mamdouh Mustafa Shawki, (1985). National security and international collective security, Cairo: Dar al-Arab renaissance, p 54. 
Morgenthea, Mans, Politics Among nations, NewYork: Alfred A. Knoff, 1967, p.25.

Muhammad, Khadija Arafa, Bush's visit and the security of the Asian-Pacific region, Journal of International Politics, Number 155, January 2004, folder 39, p 177-178.

Novosti press, 7/8/2007.

Novosti press, 8/5/2007.

Novosti press, 8/8/2007.

Novosti, 20/1/2007.

Novosti, 24/3/2007

Novosti, 27/2/2008.

Rassas, Mohamed Sayed, between Russia and the former Soviet republics, daily life, April 28, 2010.

Salim, Mohamed El-Sayed, the reality and the future of alliances in Asia, Journal of International Politics, 183, January 2011, folder 46, p 50.

Shawki, Mamdouh. (1997). National Security and International Relations, Journal of International Policy Centre for Political and Strategic Studies Al-Ahram, Number 127, January, Thirty-third Year, p 43.

Sheikh, Nourhan, political reading in Russian military doctrine, international politics, 181, July 2010, Vol 45, p 191.

Stepanova, Ekaterina. (2006). Russa’s Middle East policy: old Divisions or new, 31 Institute of world Economy and International Relations, moscow, no. 429.

Taha, Al Wali, the Organization of Shanghai will it see the birth of an influential tycoon, Retrieved from www.an_nour (December 26, 2011).

Webber, mark, "The Emergence of the foreign policy of the Russian Fedration", commuist and post communisty studies, 26(3), (September 1993), p33.

Zayat, Ahmed, Eastern Europe in U.S. foreign policy, Journal of International Politics, the number 178.2009, p 108.

\section{Web References}

http://www.alalam.jr/news, 11/11/2011.

http://wikipedia.org, 25/12/2011. 